\title{
JOHTAJUUS MUUTTUVASSA TYÖELÄMÄSSÄ
}

\section{Kohti nykyaikaista johtajuutta}

\author{
Työelämän organisaatioiden kasvu on merkinnyt eriasteisten johtamistehtävien \\ lisääntymistä. Samalla johtamistoiminnot ovat eriytyneet ja erityyppisissä \\ johtamistehtävissä tarvittavat ominaisuudet ja valmiudet ovat kehityksen myötä \\ muuttuneet sisällöltään varsin erilaisiksi.
}

Viime vuosikymmeninä tapahtunut työelämän organisaatioiden kasvu on merkinnyt eriasteisten johtamistehtävien jatkuvaa lisääntymistä. johtamistoiminnot ovat samalla eriytyneet niin, että organisaatioiden ylin johto vastaa ennen kaikkea strategisten tavoitteiden muotoilusta, niiden toteutumisen seurannasta sekä organisaation suhteista omistajiin, rahoittajiin ja muuhun yhteiskuntaan. Keskijohto huolehtii puolestaan eri tulosyksiköille asetettujen strategisten tavoitteiden toteuttamisesta, kun taas alemman esimieskunnan tehtäväksi jää varsinaisten suorittavien toimintojen ohjaaminen ja valvonta. Erityyppisissä johtamistehtävissä tarvittavat ominaisuudet ja valmiudet ovat tämän kehityksen myötä kehittyneet sisällöltään varsin erilaisiksi.

Samaan aikaan vallitsevat johtamiskulttuurit ovat läpikäyneet suuria muutoksia. Tiukan kurin sekä alaisten suoritusten yksityiskohtaisen ohjaamisen ja valvonnan sijasta tämän päivän työelämässä arvostetaan demokraattisempaa johtamista. Uuden johtamistyylin keskeisiin elementteihin kuuluvat muun muassa alaisten kuunteleminen, heidän näkemystensä huomioon ottaminen päätöksiä tehtäessä sekä vaikutusvallan ja vastuun hajauttaminen sinne, missä itse tulokset varsinaisesti tehdään. Esimiehiä rekrytoitaessa heidän kykyihinsä tulla toimeen ihmisten kanssa ja motivoida alaisiaan kiinnitetään entistä enemmän huomiota. Heidän johtamistaitojaan pyritään myös kehittämään eteenpäin muun muassa entistä laajemmaksi ja monimuotoisemmaksi kehittyneen esimies- ja johtamiskoulutuksen avulla. Tältä osin työelämä näyttää siten olevan kehittymässä inhimillisempään ja tasa-arvoisempaan suuntaan, vaikka muutokset tapahtuvat osin hitaasti ja esimerkkejä vanhakantaisesta autoritaarisesta johtamisesta löytyy edelleen aivan liikaa.

\section{Johtamisen uudet piirteet kiristyvän kilpailun oloissa}

Kiristyvä kilpailu markkinoista on pakottanut viime vuosien aikana monet liike-elämän organisaatiot muuttamaan radikaalisti perinteisiä toimintatapojaan. Yritykset ovat karsineet kustannuksiaan, niiden henkilöstömääriä on vähennetty, ja heikoimmin kannattavista ja yrityksen ydinbisneksen ulkopuolelle kuuluvista toiminnoista on saatettu luopua kokonaan. Samalla yritysten jäljelle jäävä henkilöstö joutuu sitoutumaan entistä kunnianhimoisemmiksi viritettyihin tulostavoitteisiin.

Sisäisesti yritykset ovat pyrkineet päätäntärakenteidensa madaltamiseen ja byrokratian keventämiseen. Organisaatioiden keventämisen malleja saatetaan hakea kevyen tuotannon filosofiasta (Womack \& Jones 1996), liiketoimintaprosessien uudelleenarvioinnista (Hammer \& Champy 1993) tai ns. netto-organisaatioajattelusta. Niiden tuloksena saattaa olla organisaatiorakenne, jossa yrityksen ylimmästä johdosta vastaavat suhteellisen pienet esikunnat. Niiden alapuolella ovat pitkälti itsenäiset sekä keskenään joskus ankarastikin kilpailevat erilliset tulosyksiköt. Eri 
tulosyksiköt ovat puolestaan organisoituneet keskenään verkostomaisessa yhteistyössä toimiviksi tiimeiksi, jotka kantavat pitkälti itse vastuun omista toiminnoistaan. Tyypillisenä best practice-esimerkkinä mainitaan usein ABB:n piirissä konsernin muodostamisen yhteydessä toteutettu toimintojen laajamittainen uudelleenorganisointi. Viime aikoina kirjallisuudessa on tosin esitetty epäilyjä siitä, missä määrin retorinen puhe organisaatioiden keventämisen välttämättömyydestä on johtanut tosiasiallisiin muutoksiin yritysten hallinnossa. Esimerkiksi Yhdysvalloissa on löytynyt evidenssiä suurten yritysten johtamisbyrokratioiden paisumisesta entistä suuremmiksi. (Ks. Gordon 1996, 33-60.)

\section{Yritykset ovat pyrkineet päätäntärakenteidensa madaltamiseen ja byrokratian keventämiseen. Tuloksena saattaa olla organisaatiorakenne, jossa ylimmästä johdosta vastaavat varsin pienet esikunnat ja niiden alapuolella on pitkälti itsenäiset, keskenään joskus ankarastikin kilpailevat tulosyksiköt. On tosin esitetty epäilyjä siitä, missä määrin retorinen puhe organisaatioiden keventämisen välttämättömyydestä on johtanut todellisiin muutoksiin hallinnossa.}

Tällä tavoin uudistuneissa organisaatioissa esimiehet joutuvat kaikilla tasoilla huolehtimaan ensisijaisesti siitä, että kulloinkin asetetut tulostavoitteet tulevat todella saavutetuiksi. Tämä ei välttämättä anna tilaa kovin suurelle inhimillisyydelle tai henkilöstön erilaisten tarpeiden huomioonottamiselle, vaan pikemminkin esimiesten on pyrittävä ottamaan kaikki irti heidän johdettavakseen osoitetusta henkilöstöstä. Esimiesten täytyy myös kyetä tarvittaessa hankkiutumaan eroon sellaisista alaisista, jotka eivät kykene pysymään mukana tulosten tekemisen tahdissa tai olemaan tarvittaessa riittävän joustavia esimerkiksi työaikojen suhteen. Monesti kuitenkin uudelleenjärjestelyjä toteutettaessa esimiesten oma asema saattaa joutua kaikkein pahimmin uhatuksi. Päätäntärakenteiden madaltuessa esimiehille ei ehkä avaudu enää samankaltaisia uralla etenemisen mahdollisuuksia, kuin mihin ennen on totuttu. joskus esimiehet saattavat joutua ylenemisen sijasta siirtymään alaspäin uraportailla, ja jotkut esimiehistä saattavat menettää kokonaan työpaikkansa.

Toisaalta juuri entistä korkeampiin tulostavoitteisiin pyrkivissä sekä tiimimäisesti työskentelevissä organisaatioissa johtamisen rooli muodostuu entistä merkittävämmäksi. Esimiesten toimenkuva muuttuu alaisten työn välittömästä ohjaamisesta ja valvonnasta kohti sellaista työskentelytapaa, jossa hallitseviksi tehtäviksi muodostuvat oman tiimin ja sen jäsenten valmentaminen, tiimin kannustaminen jatkuvasti parempiin tuloksiin sekä tiimin työskentelyedellytysten turvaaminen. Mitä ankarampien tulostavoitteiden parissa ihmiset joutuvat kamppailemaan, sitä suurempi merkitys esimiesten johtamistavoilla on työyhteisöjen toimivuuden kannalta. Esimiesten toiminnasta riippuu oleellisesti muun muassa se, miten tiimit saavat tietoa työnsä tuloksista ja yleisemminkin oman työpaikkansa asioista, miten työyhteisössä esiin nousevat ongelmat ja ristiriidat ratkaistaan sekä miten ihmiset viihtyvät omassa työssään.

Tämänkaltaiset organisaatioiden yleisten toimintatapojen muutokset ovat lähteneet alkujaan liikkeelle yrityssektorilta. Viime aikoina samankaltaiset muutostrendit ovat kuitenkin alkaneet vaikuttaa entistä selvemmin myös julkisella sektorilla. Valtioiden pyrkiessä hillitsemään julkisen velan kasvua ja alentamaan veroja julkissektorin organisaatiot joutuvat lisäämään määrätietoisesti omaa tuottavuuttaan sekä uudistamaan omia toimintatapojaan. Niin sanotun 'uuden julkisen johtamisen' (esim. Hughes 1994) tunnusten alla yksityisen sektorin piirissä kehitettyjä toiminnan organisointi- ja johtamistapoja onkin alettu soveltaa entistä laajemmin kaikilla keskeisillä julkisen palvelutuotannon aloilla. 


\section{Laihasta tehokkuudesta toimintojen jatkuvaan uudistumiseen}

1990-luvun alkuvuosien laman käännyttyä uuteen kasvun vaiheeseen yritysten toimintojen kehittämisestä käyty keskustelu on saanut jossakin määrin uudentyyppisiä painotuksia. Yritysjohtoa on muistutettu siitä, että yritykset eivät voi menestyä yksinomaan leikkaamalla kustannuksiaan ja tehostamalla jäljelle jääviä toimintojaan. Niiden on kyettävä myös uudistumaan, kehittämään uudentyyppisiä tuotteita, valtaamaan uusia markkinoita sekä mobilisoimaan uusia resursseja. Innovatiivisuuden vaatimus ei voi myöskään rajautua koskemaan vain yritysten ylintä johtoa, vaan organisaatioiden on kyettävä oppimaan sekä kehittämään uudenlaisia liikeideoita, tuotteita ja toimintatapoja kaikilla toiminnan tasoilla (Hamel \& Pralahad 1994).

Eräs tämän päivän innovatiivisten yritysten tärkeimmistä ominaisuuksista on niiden kyky käsitellä tietoa. Voidaan jopa puhua Nonakan ja Takeuchin tavoin 'tietoa luovista yrityksistä' (Nonaka \& Takeuchi 1995) sekä tehtaiden muuttumisesta jatkuvan oppimisen laboratorioiksi (Leonard-Barton 1992). Tietoa sinänsä on yrityksissä luonteeltaan hyvin erilaista, ylimmän johdon tuottamasta virallisesta tulos- ja strategiainformaatiosta aina operatiivisella tasolla muodostuvaan informaaliseen tietämykseen saakka. jatkuvaan uudistumiseen pyrkivän organisaation menestymisen kannalta avainasemaan nousee tällöin keskijohto, jonka keskeisenä tehtävänä on sovittaa toiminnan erilaiset logiikat toisiinsa niin, että toiminnasta saadut kokemukset välittyvät asianmukaisesti uusien strategioiden muotoiluun ja että tavoitteeksi asetetut strategiat muotoutuvat myös käytännössä operatiivista toimintaa ohjaaviksi periaatteiksi. Tällaisesta näkökulmasta käsin voidaan puhua jopa keskijohdon merkityksen uudelleenkeksimisestä. Samalla on jouduttu havaitsemaan, että lamavuosien aikana äärimmäisen ohuiksi trimmatuissa organisaatioissa on saatettu saneerata pois juuri ne resurssit, joita yritykset olisivat tarvinneet tulevan kehityksensä turvaamiseen (Mintzberg 1996, 62).

\section{Yritykset eivät voi menestyä yksinomaan leikkaamalla kustannuksiaan ja tehostamalla jäljelle jääviä toimintojaan. Niiden on kyettävä myös uudistumaan, kehittämään uudentyyppisiä tuotteita, valtaamaan uusia markkinoita sekä mobilisoimaan uusia resursseja.}

Jatkuvasti kehittymään pyrkivissä ja keskenään verkottuvien tiimien varaan rakentuvissa yrityksissä työtä tehdään usein projektimaisesti. Organisaatio rakentuu tällöin alati muuttuvaksi matriisiksi, jossa esimiehillä on avainrooli eri suuntiin ulottuvien verkostoyhteyksien rakentamisessa. Esimerkiksi asiakaskohtaisesti suunniteltuja pitkälle erikoistuneita tuotteita valmistavassa organisaatiossa tuotteiden suunnittelu, myynti ja valmistus rakentuvat entistä enemmän ajallisesti päällekkäisiksi prosesseiksi. Tällaisen toimintatavan mahdollistamiseksi myynnin, tuotekehityksen, tuotannonsuunnittelun, hankinnan ja valmistuksen tiimit joutuvat pitämään jatkuvasti yhteyttä keskenään. Eräänä kärkiesimerkkinä tehokkaasti rakennetusta matriisimaisesta toimintatavasta voitaneen tänä päivänä pitää Microsoftia ja sen tapaa hallita omia tuotekehitysprojektejaan (Cusumano \& Selby 1995).

Verkottuvien tiimien varaan rakentuvissa organisaatioissa myös eri johtamistasojen välillä perinteisesti vallinneet rajat muodostuvat entistä liukuvammiksi. Vaikka yritysten ylimmän johdon vastuulla on entistä kiteytetymmin nimenomaan yrityksen toiminta-ajatuksen ja keskeisten strategisten tavoitteiden muotoilu, strategiat voivat toteutua käytännössä vain siinä määrin kuin ne todella välittyvät myös operatiivisella tasolla työskentelevän henkilöstön toimintaa ohjaaviksi periaatteiksi. Tässä ei ole kyse ainoastaan tehokkaasta tiedottamisesta ja motivoinnista, vaan toiminta-ajatuksen saattamisesta jatkuvan keskustelun ja kriittisen uudelleenarvioinnin kohteeksi 
kautta koko organisaation, jolloin myös organisaation strategian ensi linjan toteuttajien kokemukset vuorovaikutuksesta asiakkaiden kanssa välittyvät strategiasta käytävään keskusteluun. Samoin on tärkeää, että eri tulosyksiköt ja tiimit omaksuvat riittävän strategisen otteen omiin tulostavoitteisiin pyrkiessään (uudenlaisen strategiakonseption hahmottelusta ks. esiin. Wall \& Rye Wall 1995).

Edelläkuvatun kaltaisten muutosten voidaan tietenkin väittää koskettavan lähinnä vain suuria ja kansainvälisesti orientoituneita yrityksiä, joiden rooli työllistäjinä saattaa vastaisuudessa pikemminkin vähentyä kuin kasvaa. Toisaalta jatkuvan uudistumisen ja toimintojen kehittämisen paineet tuntuvat tänä päivänä kaikkialla yhteiskunnassa, jossa ei enää voida vetää selkeitä rajoja esimerkiksi kansantalouden 'avoimen' ja 'suljetun' sektorin välille. ja vaikka vastuu uusien työpaikkojen luomisesta lankeaakin tulevaisuudessa entistä selkeämmin pienten ja keskisuurten yritysten vastuulle, rajat suurten ja pienten yritysten välillä ovat muodostumassa tietyssä määrin liukuviksi sitä mukaa kun suuret konsernit hajauttavat organisaatioitaan suhteellisen pieniksi tulosvastuullisiksi yksiköiksi, joiden menestyminen rakentuu ennen muuta niissä omaksutun sisäisen yrittäjyyden varaan.

Ylimmän johdon vastuulla olevat yrityksen strategiat voivat toteutua käytännössä vain siinä määrin kuin ne todella välittyvät myös operatiivisella tasolla työskentelevien henkilöiden toimintaa ohjaaviksi periaatteiksi. Kysymys ei ole vain tiedottamisesta ja motivoinnista, vaan toiminta-ajatuksen saattamisesta keskustelun ja kriittisen uudelleenarvioinnin kohteeksi kautta koko organisaation.

Oman erityisen työelämän ja johtamistoimintojen alueensa tulevat kuitenkin todennäköisesti muodostamaan senkaltaiset studiotyyppiset asiantuntijaorganisaatiot, joissa tiettyjen alojen erityisosaajat kokoontuvat kiinteästi yhdessä työskenteleviksi tiimeiksi. Tämän kiinteän yhdessätyöskentelemisen ei tarvitse välttämättä merkitä tiimien jäsenten ajallista ja tilallista yhdessäoloa, vaan toiminnot saatetaan järjestää hyvinkin pitkälti virtuaaliyrityksen toimintaperiaattein (Birchall \& Lyons 1995). Mutta käytännön järjestämismuodoistaan huolimatta tämäntyyppisten asiantuntijaorganisaatioiden johtaminen vaatii aivan erilaista johtamista, kuin mihin muualla on totuttu. Pelkkä muodollinen asema ei vielä riitä johtajuuden saavuttamiseen, vaan esimiehen on kyettävä saavuttamaan työyhteisönsä jäsenten luottamus oman professionaalisen osaamisensa kautta. Samalla esimiehen on kyettävä luomaan sellainen työympäristö, jossa ihmiset voivat kokea kehittyvänsä, joka antaa heille riittävät mahdollisuudet kehittää omaa ammatillista osaamistaan ja jonka he odottavat tarjoavan heidän kannaltaan kiinnostavia töitä myös tulevaisuudessa.

Juuri studiotyyppiset asiantuntijaorganisaatiot (jollaisen voi muodostaa vaikkapa urheilujoukkue, sijoitusyhtiö tai ammattiteatteriryhmä) tulevat rakentumaan kaikkein selkeimmin sellaisiksi korkean sitoutumisen työyhteisöiksi, joissa ei välttämättä lasketa työtunteja tai katsota kellokorttiin silloin, kun keskeisimmät projektit ovat valmistumisvaiheessaan. Tekijöilleen tällaiset projektit ja niitä toteuttavat yhteisöt saattavat muodostua tavattoman attraktiivisiksi, mutta inhimilliseltä ja muun yhteiskunnan kannalta katsoen ne eivät välttämättä ole kovin terveellisiä. juuri siksi työelämän tulos- ja joustovaatimusten lisääntyessä entistä tärkeämmäksi johtamisen ulottuvuudeksi nousee työelämän responsiivisuuden vaatimuksista huolehtiminen. Niin miehillä kuin naisillakin tulee olla mahdollisuus sovittaa työn ja muun elämän vaatimukset mielekkäällä tavalla toisiinsa, ja esimiesten tehtävänä on saattaa tämä mahdollisuus riittävän selkeästi omien alaistensa tietoisuuteen. Johdonmukainen kiinnipitäminen responsiivisuuden periaatteesta merkitsee tietenkin myös sitä, että esimiesten on kyettävä löytämään vaihtoehtoiset keinot asetettujen tulostavoitteiden saavuttamiseen. 


\section{Työelämän uudet riskit johtamisen haasteena}

Yksi läntisten teollisuusmaiden tämän hetken suurimmista sosiaalisista ongelmista on ihmisten kokema suuri epävarmuus siitä, millaiseksi heidän asemansa työelämässä tulee muodostumaan tulevaisuudessa. Yritykset ja laitokset ovat joutuneet yksi toisensa jälkeen eriasteisten saneeraustoimien kohteeksi, ja 'varmojen' työpaikkojen löytäminen on muodostunut entistä vaikeammaksi. Myös hyvin menestyvät yritykset saattavat viestiä henkilöstölleen, etteivät ne pysty takaamaan automaattisesti töiden jatkuvuutta, vaan töiden jatkuminen on täysin kiinni asiakkaista sekä heidän halukkuudestaan maksaa organisaation tuotteista ja palveluista myös tulevaisuudessa. Uutta työvoimaa rekrytoidessaan organisaatiot pyrkivät mahdollisimman joustaviin työsuhdejärjestelyihin, mikä on johtanut erilaisten epätyypillisten työnteon muotojen selvään lisääntymiseen.

Tästä voitaisiin tietenkin helposti päätellä, että henkilöstön kannalta hyvään johtamiseen kuuluu töiden jatkuvuuden varmistaminen niin pitkälle kuin se nykyisissä oloissa on ylipäätään mahdollista. Eräät viimeaikaiset tutkimustulokset viittaavat kuitenkin siihen, että näin ei ole välttämättä asian laita. Esimerkiksi yhdysvaltalainen Charles Heckscher on tutkiessaan keskijohdon asemassa tapahtuneita muutoksia laajoja uudelleenorganisointiprosesseja läpikäyneissä pohjoisamerikkalaisissa yrityksissä havainnut, että vastavuoroiset lojaliteettisiteet säilyttämään pyrkivissä organisaatioissa toimihenkilöt olivat sinänsä tyytyväisiä siitä, että heidän työsuhteensa pyrittiin turvaamaan. Samalla heidän muutoksiin sopeutumisensa oli kuitenkin tapahtunut hyvin defensiivisellä tavalla. Itse muutosprosessit olivat olleet paljon kriittisempiä sellaisissa yrityksissä, joissa vanhat lojaliteettisiteet oli selkeästi purettu ja joissa toimihenkilöille ei annettu mitään sitovia tulevaisuutta koskevia lupauksia. Mutta toisaalta juuri viimemainituissa oli havaittavissa merkkejä uudenlaisen yhteisyyden rakentumisesta ihmisten yhteisten osaamisalueiden ympärille. Työtä tehtiin selkeästi tietoisina tulevaisuuden epävarmuustekijöistä, mutta samalla pyrkien vahvistamaan itse kunkin työllistettävyyttä siinä vaiheessa, kun olemassaolevat projektit on saatettu päätökseen (Heckscher 1995; työelämän uudenlaisten sosiaalisten sitoumusten rakentumisesta ks. myös Hakim 1994).

Ylipäätäänkin nykyisin on perusteltua olettaa, että me olemme vähitellen siirtymässä kohti joustavan projektimaisen työnteon yhteiskuntaa, jossa perinteiset vakinaiset työsuhteet ja lineaarisesti etenevät työurat muuttuvat yhä harvinaisemmiksi. Entistä useammat läntisten teollisuusmaiden kansalaiset tulevat ansaitsemaan elantonsa enemmän tai vähemmän määräaikaisista projekteista, joihin he kiinnittyvät muodoiltaan hyvin vaihtelevien työsuhteiden tai sopimusten välityksellä. Myös organisaatiot rakentavat toimintansa kokoonpanoltaan alati vaihtuvien tiimien varaan, vaikka erilaisten avainosaamisen alueiden kehittyminen tuo työelämään myös tiettyä aitoa pysyvyyttä. Tällaisissa olosuhteissa keskeiseksi hyvän johtamisen kriteeriksi muodostuu työsuhteiden pysyvyyden sijasta kaikille henkilöstöön kuuluville tarjottu mahdollisuus kehittää jatkuvasti osaamistaan niin, että eri projekteihin osallistuessaan he kykenevät samalla lisäämään omaa työllistettävyyttään. Yhteiskunnan asiaksi jää puolestaan perustavien sosiaalisten turvaverkkojen rakentaminen niin, että ihmiset todella uskaltavat ottaa riskejä ja käyttäytyä joustavasti työmarkkinoilla siten kuin nykyaikaisen dynaamisesti kehittyvän verkostotalouden tehokas toiminta edellyttää. Nykyisinhän nämä verkot on rakennettu hyvin pitkälti nimenomaan pysyviksi oletettujen normaalityösuhteiden varaan, jolloin saneeraustoimien kohteeksi joutunut henkilö saattaa ajautua herkästi yhä vaikeampaan syrjäytymiskierteeseen. 


\section{Tarvitaanko tulevaisuudessa johtamista?}

Pidemmällä aikavälillä me voimme visioida kehitystä kohti sellaista itseohjautuvaa yhteiskuntaa, jossa suurin osa yhteiskunnan tarvitsemasta työstä tehdään osaavien ihmisten muodostamissa matalissa ja tiimimäisissä organisaatioissa. 'Johtamisen' erillisenä toimintana voidaan tällöin ajatella menettävän merkitystään sitä mukaa kun keskenään yhteistyössä toimivat ihmiset oppivat johtamaan entistä paremmin itse itseään. Itse en kuitenkaan ole taipuvainen pitämään tämänkaltaisten itsehallinnollisten visioiden toteutumista kovinkaan todennäköisenä. Päin vastoin kaikki vuorovaikutukselliseen ja koordinoituun toimintaan perustuvat organisaatiot tulevat vastaisuudessakin tarvitsemaan omat johtajansa samalla tavoin kuin orkesterit tarvitsevat kapellimestarinsa, elokuvat ohjaajansa ja urheilujoukkueet valmentajansa. johtamisen tavat, kulttuurit ja sukupuolimääreet tulevat toki muuttumaan oleellisesti nykyisestään, ja näin tapahtuu sitä selkeämmin, niitä pidemmälle me etenemme kohti globaalisti integroitunutta jälkiteollista tietoyhteiskuntaa.

\section{KIRJALLISUUS}

Birchall, D., Lyons, L. (1995): Creating Tomorrow's Organization. Unlocking the Benefits of Future Work. London: Pitman Publishing.

Cusumano, M.A., Selby R. W. (1995): Microsoft Secrets. New York: The Free Press.

Gordon, R. (1996): Fat and Mean. The Corporate Squeeze of Working Americans and the Myth of Managerial 'Downsizing'. New York: The Free Press.

Hakim, G. (1994): We Are All Self-Employed. San Francisco: Berrett-Kohler Publishers.

Hamel, G., Pralahad, C.K. (1994): Competing for the Futire. Breakthrough Strategies for Seizing

Control of Your Industry and Creating Markets for Tomorrow. Boston: Harvard Business School

Press.

Hammer, M., Champy, J. (1993): Reengineering the Corporation. A Manifesto for Business Revolution. New York: Harper Business.

Hecksber, G. (1995): White-Collar Blues. Management Loyalties in an Age of Corporate Restructuring. New York: Basic Books.

Hughes, O.E. (1994): Public Management and Administration: An Introduction. Hong Kong: MacMillan Press.

Leonard-Barton, D. (1992): The Factory as a Learning Laboratory. Sloan Management Review Fall, 23-38.

Mintzberg, H. (1996): Musings on Management. Ten Ideas Designed to Rile Everyone Who Cares About Management. Harvard Business Review Vol. 74, 4, 61-67.

Nonaka, I., Takeuchi, H. (1995): The Knowledge-Creating Company. New York: Oxford University Press.

Wall, S.J., Rye Wall, S. (1995): The New Strategists. Creating Leaders at All Levels. New York: The Free Press.

Womack, J, Jones, A. (1996): Learn Thinking. New York: Basic Books. 